\title{
A Psycholinguistics Analysis: How do ESL Learners in Higher Education Write Paragraphs?
}

\author{
Faridatun Nida \\ Universitas Amikom Purwokerto, \\ Jl. Letjend Pol. Soemarto No.126, Watumas, Purwanegara, Kec. Purwokerto \\ Utara, Kabupaten Banyumas, Jawa Tengah 53127 \\ faridatun.nida@amikompurwokerto.ac.id
}

Article History: Submitted on 17th October 2021; Accepted on 21th December 2021; Published on 30th December 2021

\begin{abstract}
Having the ability to write paragraphs is important, especially for students in higher education. Nevertheless, mastering the skill of writing is not easy, takes time, and sometimes is boring. Looking for the alternative leads the researcher to do a research with the aim of finding the favourable topics of writing and understanding the difficulties in writing a paragraph using psycholinguistics approach. Students are firstly given the explanation about paragraph including the intrinsic and extrinsic elements of it. Then, they are instructed to write a paragraph in several steps but are free to choose their own topics. Their works then are analysed in order to see the topic chosen by the students in writing paragraphs. Next, the analysis is focused on the structure and the ideas they deliver through the sentences. The results show that the topics chosen are about things relate to their real life, like health, technology, food, sport, and natural disaster. Meanwhile, dealing with the structures and the ideas, the students' works are divided into five categories. The two dominant categories are expected structure but unexpected content; and expected structure and expected content. Hence, the findings will be taken into the consideration for the lesson material. Besides, the student's skill of writing and their problem in writing that is shown by the analysis of structure and content will be the focus of lesson discussion. Therefore, the students are expected to have fun learning in writing.
\end{abstract}

Keywords: ESL learner, higher education, writing paragraph 


\section{INTRODUCTION}

In the context of language learning, students should master four skills. They firstly need to get listening and reading, that is to hear and read the messages as an input to become acquainted with the language. After getting the input, the students are expected to give the output that is shown by the skill of speaking and writing to produce messages. In fact, reaching out the skill of writing is regarded as the last and the most difficult to be perceived by the students (Ampa \& Quraisy, 2018; Dewi, 2016; Isgiarno et al., 2020).

At the level of higher education, students are considered to belong to advanced learners (Flores, 2021). They have got the basic skill of how to produce a message in the form of sentences. Despite the fact that they could write a sentence and understand plenteous theory of writing, it does not mean that the students could master the skill of writing and have a skill of producing a proper text. Some of them head problems in the way of applying the theory and putting it while writing a text (Fatmah et al., 2020). The others had the problems of telling ideas (Anh, 2019), taking off the influence of mother language (Alshammari, 2020; Ariyanti, 2016), and applying grammatical rules (Setiyorini et al., 2020). Meanwhile, joining the class of writing is tedious since students conceive that the teacher would give them instruction of having much practice of writing (Tuan, 2010). Strategies like making a peer feedback (Saptenno \& Souisa, 2021), using flash card (Indriyastuti, 2019), applying blended-learning (Huda, 2018), running habits of mind (Koura \& Zahran, 2017), building interaction in writing class (Monalisa, 2017), applying STOP strategy (Okasha \& Hamdi, 2014), and involving cognitive aspect (Muslim, 2014) have been applied as the solution. Yet it still gives pros and cons. Hence, the problem arose.

Teachers might need to get acquainted with the students' skill of writing English paragraphs and find a better approach to teach the students about writing. It can be considered as an exertion to fulfil their role as facilitator and coach of their students (Hidayati, 2018). Moreover, teachers need to build enjoyable learning. Motivating students to write text on the topic of their interest is a kind of providing the platform of writing skill improvement (Mohammad \& Hazarika, 2016). Furthermore, making an equality in communication could make them feel familiar and give a sense of happiness so that it creates students' good mood. Such factors are beneficial for the success of learning (Kadir, 2017). Thus, it leads the researcher to do further analysis.

Dealing with students' mood in the learning process, there is a psycholinguistics that is regarded as the precious approach to be involved. This approach has been flowering in some research and it is stated that psycholinguistics is an approach that concerns the mentality of students to be a 'bridge' of successful learning (Kurniawan et al., 2017; Natsir, 2017; Sabarua, 2017). Yet, none of the research is found as the picture of 
psycholinguistics involvement in solving such problems of writing learning.

The present research brings the idea of applying psycholinguistics since mentality plays a role in the learning process. Mental process in language learning is involved when the students deliver their ideas and thoughts (Sidabutar, 2016). From this viewpoint, psycholinguistics has utility dealing with the flow of expression. This can be applied to find the preferential topics that the students choose in the writing paragraph. Furthermore, the study of mentality, especially about the memory, mind and language, can give a contribution in creating solutions dealing with the problem of writing skill (Sidabutar, 2016). It leads to the implication that psycholinguistics is also helpful for the analysis of the frequent difficulties that are faced by the students in writing paragraphs.

None of the research has been found to solve the problem from the view of psycholinguistics. The previous research has broadening their knowledge about the relation between psycholinguistics and language learning (Kadir, 2017; Lisnawati, 2008; Natsir, 2017; Sabarua, 2017) but none of them are making research of finding learning methods using the viewpoint of psycholinguistics to give improvement in reaching better learning outcomes. Approaches like need analysis and questionnaire are seen as the way to consider their future lesson plan (Ampa \& Quraisy, 2018). Hence, the present research is proposed to enrich the literature.

The sequence of explanation above concludes that the background of the research arises from the problem found in writing class that is identically boring and not motivating. The researcher tries to solve the problem through the mental approach, that is understanding the preferable topic and the frequent difficulties the students have. In the future, it is expected that the findings can be an approach to create a sense of fun and enjoyment in the writing class since the student's mood in learning can help the teacher to achieve the objectives of the lesson. In addition, it gives several clues of students' ability in writing as the consideration to arrange the lesson plan and material.

\section{METHOD}

Running the adapted method of previous research is regarded as a way of bearing trustworthy, credible findings. Besides, choosing a precise method to be involved in the aim of answering the research problem is another important consideration. Therefore, this research chooses a designbased research methodology (Flores, 2021).

Designed-based research method in the form of iterative is applied to do experimental assessment. The students are organized to the same questions, appeared in one version and extended to free writing under the instruction of the test. This is done in order to see their manner, their responses to make meaning through their writing (Flores, 2021). 
Students who are involved in this research are in their third semester of higher education, Universitas Amikom Purwokerto. Their studies basically lay not in language studies or linguistics, but computer and technology. As a result, English class in two semesters is not enough to teach them deeply and regularly about writing. The limited time of learning English during their education leads the present research to give solutions and answer to the problems through some steps.

The lecture initially gives students the description and explanation of the paragraph including the part of paragraph and element of it. This is done to help the students have an imagination of what they have to do. The instruction of making paragraphs is given gradually to give them time to consider the topic of the paragraph and the way to convey the information. As they complete the instruction, the students submit their work. It is documented in a folder (Ivana et al., 2019). Hence, the submitted works are seen as the data of this research.

Getting the data leads to the next step to reach the findings, that is analysis. In this step, psycholinguistics of discourse comprehension is involved to get the information of topic preferences and answer suitability. Those points become the concern since the topic is considered as the key to the whole chains of paragraphs, while the suitability of the answer will show their understanding of material and instruction given.

Besides expecting to find a variety of topics, the results are hypothesized to fall into five categories; no writing, writing in expected structure but with unexpected content, writing in expected content but unexpected structure, writing in unexpected content and structure and writing in expected structure and content. This categorization helps the researcher to understand the problem of writing and the mistakes the students often made in writing a paragraph.

After obtaining the result of analysis, the researcher presents the finding in forms of table and description. Table is used to display the quantity dealing with the topics and its percentage. Meanwhile, the description is written to explain the quality dealing with the analysis of topic, structure and the problem of writing.

\section{FINDINGS AND DISCUSSION}

Written texts in the form of (a) paragraph(s) produced by the ESL students give some interpretations and overviews. It interprets the topics they preferably choose to write. It might not always be something they are fond of but it surely something that stuck in their mind. Here are some topics that are found after doing the analysis. 
Table 1:

Variety of Topics

\begin{tabular}{|c|l|c|}
\hline No & \multicolumn{1}{|c|}{ Topics } & Amount $(\%)$ \\
\hline 1 & Health & 29,6 \\
\hline 2 & Technology & 20,3 \\
\hline 3 & Food & 20,0 \\
\hline 4 & Hobby & 12,5 \\
\hline 5 & Business & 5,3 \\
\hline 6 & Phenomenon & 3,2 \\
\hline 7 & Sport & 3,2 \\
\hline 8 & Beauty & 2,8 \\
\hline 9 & Art & 1,6 \\
\hline 10 & Etc & 1,5 \\
\hline
\end{tabular}

Topics of their texts relate to something around them, because they are interested in it or because it is stuck in their mind. As seen on the table, health becomes the dominant topic chosen by the students. It recently became a-lot-to-talk since the emergence of corona virus and Covid-19 pandemic. The phenomenon leads people to be more aware of health. It also affects the students in choosing the topic of writing. Another oft-chosen topic is technology. It is not surprising since their educational background is closely related to computers and technology. Besides, they are thick with its usage for everyday life. In fact, the paragraphs with the topics of technology are not as technical as they learned. They take it up in general, like the effect, the advantages and disadvantages of smartphones and the internet. This also shows that the students tend to choose something that they are familiar with. And the third level of mostly-chosen topics is about their interest or hobby. This thickens into their everyday and often-done activities.

The analysis not only interprets the topics, but also gives the overviews about their skill in writing. It also gives the picture of difficulties and problems they had while doing the writing. As stated on the method, the students are asked to write a paragraph. The results vary and it is nifty. Variety of responses shows that the students took the test seriously (Flores, 2021). Hence, their works are classified into five categories.

Table 2:

Student's answer

\begin{tabular}{|c|l|l|}
\hline No & \multicolumn{1}{|c|}{ Category } & \multicolumn{1}{|c|}{ Amount (\%) } \\
\hline 1 & No writing & 2,5 \\
\hline 2 & Expected structure, unexpected content & 31,2 \\
\hline 3 & Expected content, unexpected structure & 15,4 \\
\hline 4 & Unexpected structure, unexpected content & 11,7 \\
\hline 5 & Expected content, expected structure & 30,0 \\
\hline
\end{tabular}


Structure and content are separated due to its focus on the part of analysis. Structure covers the extrinsic elements and the content covers the intrinsic. Then, expected and unexpected refers to the way they do their work based on the order. Even if the topic varies, the manner of working should be similar. The similarity refers to the standard of assessment.

The assessment of expected and unexpected is done by some criterions. Dealing with the structure, the assessment is based on the extrinsic element of a good paragraph. It should consist of a topic sentence, some supporting sentences, and concluding sentence (Yunhadi, 2013). The presence of the topic sentence is signed by the statement about the idea of the paragraph as a whole in the beginning of the graph. The presence of supporting sentences is signed by the explanations that relate to the main idea stated in the topic sentence. The concluding sentence is signed by the summary of the whole information. It is written at the end of the paragraph. If the student's work contains those three elements, it could be categorized into the expected structure. If the elements are incomplete, the paragraph will categorize into unexpected.

From the point of content, the assessment is based on the intrinsic element of a paragraph. It should be unity and coherence (Dasril et al., 2019). Unity refers to the idea that becomes the focus of the one-whole paragraph. Coherence refers to the meaning relation among the sentences in that onewhole paragraph. Both are related to each other in creating the meaning and delivering the information written in the paragraph. The understanding of unity and coherence is also obtained by finding the keywords among the sentences. Its presence shows the meaning relation between the sentences. Therefore, if the student's paragraph is considered having a characteristic of unity and coherence, it is the expected criterion of a paragraph. On the contrary, if the student's paragraph does not continuously talk about the idea stated on the topic, it means the content of the paragraph is categorized as unexpected.

The largest amount belongs to 'expected structure but unexpected content'. The students were able to understand the instruction and have tried to make their work by order. They have made a structured paragraph, consisting of a topic sentence, some supporting sentences and a concluding sentence. Unfortunately, they still need to learn in making the paragraph unity and coherence. Too much information compiled disrupts the information flow. 
Picture 1:

Gadget

\section{GADGET}

Gadget is an electronic device that not only provides many benefits but also provides various impacts on its users. First, gadgets through the development of technology information and communication are increasingly rapid, of course the benefits are greatly felt by the community because it has a very strong influence in supporting human life to help with work or daily activities. Therefore, the benefits of gadgets in everyday life give great importance to every human mobility today. For example, gadgets as information media, communication media, entertainment media, learning media, even for online business activities. Furthermore, apart from providing many benefits, gadgets also cause various bad effects which usually arise due to misuse and use that exceeds normal limits. As a result, this can lead to physical and psychological health problems. So in conclusion, gadgets are able to provide various benefits. however, it should also be noted about the bad effects that occur if the use of the gadget itself gets out of control.

Source: https://bit.ly/3iDGIzN

The paragraph talks about gadgets. It is written as an order for the structure. It begins with a topic sentence on the first, then followed by supporting on the second and so forth. It ends with two concluding sentences. Unfortunately, each part lacks unity and coherence.

In the topic, the student stated two points of discussion, benefit and impact. In the supporting sentence, he wrote the benefit in only one-long sentence. Another point informed the negative impact of using gadgets followed by the benefits. Examples are also given to enhance the explanation and description. Two concluding sentences are written to close the paragraph.

The paragraph shows the student's mentality dealing with the flow of expression and the way of thinking. The student does not focus on the one idea in a paragraph. Overlapping happens when two topics of discussion are united into one paragraph. He talks about benefits and the impact in one paragraph. The paragraph on picture 1 also starts the explanation by giving information about the development of technology and repeating the statement that gadgets give influence. It is fluttering to understand the point of discussion. The round then affects the conclusion. It is stated in two sentences. Therefore, the paragraph belongs to expected structure yet unexpected content. 
Picture 2:

Social Media

Social Media
Social media is the new face of communication around the world. We can communication
with friend, family, or other people easily by the social media. We can also use social media to
follow hot news in our country and other countries. Although social media has many positive
impacts, it also has many negative impacts for its users. The negative impact of social media is
causes addiction to its users. People who addicted in social media, tend to think that viewers or
followers are important matter. Therefore, they always will try to get more likes on the next post
if now they post don't get a lot of likes from other people. Apart from that, the problem that really
obvious is an anti-social behavior. It is because everybody is really enjoy to play their phone, so
they are not aware with other people around them. In conclusion, social media definitely has a
positive side and a negative side, and to overcome the negative side of social media, depend on
ourselves to be more wise to use social media.

Source: https://bit.ly/3uN9uTj

Another problem of content dealing with unity and coherence also appears in the paragraph entitled Social Media. She consciously realized the instruction. It is shown by the use of signs; red for topic sentence, black for supporting sentence and blue for concluding sentence. Yet, the way of delivering information needs to be trained. It initially can be seen from the topic and the conclusion sentence. The topic talks about something in general but the conclusion is so specific and does not relate to each other. The supporting sentences that are written in eight sentences seem to give mixed ideas. It is predicted that in the beginning of writing, she has no specific idea but then in the middle of writing she gets it specific.

Writing a paragraph about something that is interesting for the writer brings expectation that she has a good understanding of the information. She is expected to have the capabilities of organizing information she wants to deliver. In fact, imagination does not always come in the same way. A lot of information that she wants to deliver made it overlapped and messed up the focus. The chain of words in the sentences shows her thoughts about the topic.

\section{Picture 3:}

K-pop

Topic : K-POP

Kpop or Korean pop is a type of original popular music from south Korea. In 1989 the first kpop agency was founded by a kpop figure Lee Soo Man, with the initial name SM studio, and in 1990 it changed to SM Entertainment. After SM Entertainment was established, several agencies were established. For example YG Entertainment and JYP Entertainment, and many others that exist to date. The beginning of k-pop music to foreign countries was the beginning of 2000 with the emergence of several famous artists or idols. Therefore, now there are many kpop artists who are known and liked by young people in various countries.

Source: https://bit.ly/2WSw28K 
Even though the information still talks about K-Pop, the information delivered is the mixture of the agency and the type of music. The topic is stated clearly in the beginning to talk about K-Pop definition as a type of music. Nevertheless, the next sentences that are regarded as the supporting sentence dominantly explain about the history of K-pop agency. There is a confusion in deciding the information she wants to deliver because in the end, she talks about the famous artist that was born by the agencies and does not focus only on the description of K-pop as a type of music. Similar problem is found in the paragraph below.

Picture 4:

The Impact of La Nina in Indonesia

The Impact of La Nina in Indonesia
The impact of La Nina in Indonesia can cause various disasters. First of all what is
meant by La Nina. La Nina is a phenomenon of sea surface temperature decreasing along the
eastern and central Pacific Ocean along the equator. So that the result of this phenomenon has
resulted in various disasters such as high rainfall accompanied by strong winds, floods and
landslides. Then the peak of La Nina is in December and at the same time the peak of the rainy
season in Indonesia occurs in January and February 2021 . Thus, the impact of La Nina can be
felt in various regions in Indonesia and for the first affected areas the impact of La Nina is that
the jabodetabek area was hit by heavy rain and caused flooding. Another example that is
affected by La Nina is high sea waves, such as those that occur on the south coast. Then another
disaster, namely on December 3, 2020, the Serayu river overflowed due to heavy rain causing
flooding in the Purbalingga and Banyumas areas.
So it can be concluded that La Nina causes extreme weather which results in various
disasters in Indonesia such as heavy rains accompanied by strong winds, floods and landslides.

Source: https://bit.ly/3DnGB3f

Disaster might be not something that people love but they have to be aware of. It could be stuck in their mind and for a long-term memory. The curiosity also leads them to look and search for information about it. The result is seen in one of the students' work. He wrote about La Nina.

Looking at picture 4 , the text seems to consist of two paragraphs. Writing in such a way is intended to give different results. In other words, writing each part separately might be considered as the way of organizing information. In fact, it is not the solution. Even if the second paragraph is ignored, the first is not really understandable.

At the beginning of the paragraph, it is clearly stated in the topic sentence that he would talk about the disaster caused by La Nina. Yet in delivering the information, there is some additional information that makes it messed up. Although it talks about the same disaster, the scope of the information might not be unified. The description of disaster about the definition, occurrence and the example of its happening could be compiled into one another paragraph with the topic stated about the description of $\mathrm{La}$ Nina. 
The concluding sentence is actually right to be stated. Nevertheless, its position beyond the paragraph makes it look like a separated discussion. It seems strange since the instruction gives order to compile them into one unified paragraph. This problem is also pictured in another student's work.

Picture 5:

Fixie Bikes

Fixie bikes
Fixie bikes are bikes designed for racing bikes. It is slim and also has
lightweight body. Therefore, many people like it especially the young one.
Beides for exercising, cycling is also a fun and enjoyable hobby. Here, there
are few things you need to know. Fixie bikes only use one gear which makes this
motorbike also called a fixed gear, so using this bike on an uphill road will feel heavy
when pedaled. Besides only having one gear, fixie bikes are also designed to have no
brakes, So to do braking we have to hold the pedal with all our strength until the rear
tire of the bicycle stops.The flat and thin shape of the tire makes this motorbike look
unique and cool, besides that it is also prone to damage and bending when used on
damaged and potholed roads. Fixie cannot be used for all terrain. Fixie is not suitable
for offroad, fixie is only suitable for smooth onroad tracks. Using a fixie on an
offroad track will actually accelerate the damage to the bicycle.
hrioritize braking practice by holding the pedal as hard as you can. If you can't hold
the pedals and control your bicycle, you are also at great risk of falling. But if you
have trouble braking like that, you can follow the solution above.
so for those of you who have already bought a fixie bike. I's a good idea to

Source: https://bit.ly/3lgEDLB

Fixie and fixie bikes are mentioned in every slice and it seems like it becomes the keywords that link the discussions within those paragraphs. Yet, a deeper understanding of the content could give us different results. Each part on the chain does not talk about the same thing. The first paragraph talks about the general and physical description of fixie bikes. The second talks about the features and design of fixie bikes. Even in the beginning it is written that fixie is designed for racing bikes, but the next paragraph states the different things that are beyond the design but also features of the bikes. The third paragraph gives advice for the reader before having fixie bikes. It is confusing for the readers since the information is overwhelming but unorganized. Therefore, it needs to be rearranged to make it easily understandable and readable because the idea of the paragraph is actually good but not for the flow of information and the form of written text. Therefore, picture 5 is the data that belongs to unexpected structure and unexpected content. 
Picture 6:

Caring for Others

There are so many things we will get from caring for
others.
Caring for others is an attitude that gets us a lot of benefit. From a
caring attitude towards others, there will be many things we get.
Including the way of sustenance will be broad and open because no
matter how small your gift to others they will definitely remember
with pleasure.
Besides that social relations are well established with the community,
become a good role model for others, such as increasing gratitude for
what we have today and sharing goodness with each other because
they will do good according to the good they get.
So the attitude of caring for others is very important because it
provides many benefits for ourselves that we can do anywhere and
anytime. Because all the good we give, today and tomorrow, there
will definitely be lessons.

Source: https://bit.ly/3Ao4fKN

Unexpected structure does not always happen together with unexpected content. It is shown in picture 6. The content is well done. It talks about the same topic, the benefits of caring for others. The student is considerably good in delivering information, yet she might not really understand the instruction. It caused her to write the answer into three separate parts. It is exactly not suited to the instruction.

The text consists of three paragraphs. First paragraph tells about the topic sentence and the first benefit of caring. The second benefit is written in paragraph two. The conclusion to end the writing is written in paragraph three.

Even if the content is relatable, writing them into splits makes them seem to be having different discussions. The use of conjunctions like 'beside that' and 'so' is not enough to mark and give it a look of compound. This is because such kind of writing is possibly making them have a compiled discussion. Writing one topic in a separated paragraph is possible if the discussion has further detail of information. Therefore, picture 6 shows the data that belongs to expected content but unexpected structure. 
Picture 7:

Bad effect of internet on students

Bad effect internet on students
The internet has become unresolved bad efffect for students. Because
many students are becoming addicted to the internet. They spend
much time playing mobile games like mobile legends or just surfing
the net without any particular reasons. Accordingly, the time they
spend on studying automatically reduces, which in turn causes lower
academic achievement. Moreover, few of them go to the extreme,
becoming the serious internet addicts, and they even refuse to go to
school as they cannot escape from the trap of the internet.

Source: https://bit.ly/3DkZV0O

The structure of paragraph actually is not the prior cause of unreadable information. Picture above gives an example that incompletestructure of the paragraph is still possible to make the information understandable. This is because understandability is built by coherence and cohesion.

The information on picture 7 begins with the topic, stating that it is going to talk about the bad impact of the internet. Confusion happens after reading the paragraph since there are so many repetitions of explanations. Yet, the point still could be understood. The concise and efficient word usage in conveying the information is regarded to be better.

Picture 8:

Owning a pet

Owning A Pet
Pets have a separate role in the life of their owners. If the owner really loves his pet,
they will give whatever is best for their pets. They will do many fun activities, such as
playing together, feeding them, and even taking their pets for a walk outside the house.
Many activities that are doing together creates a special relationship between the two. This is
evident in several things that pets do, for example if the owner is sick, the pet will look
gloomy and will wait for the owner by sleeping beside him, another example is if the owner
is sad, they will seek attention, so the owner interested to play together. Beside that, pet will
also make funny acts so the owner forgets the things that make they sad. The last example, if
the owner is away and doesn't come home, the pet will wait in front of the house, and if the
owner comes home, a pet will immediately run to the owner and kiss the owner. Owning a
pet has its own privileges for the owner. This is because pets can be used as friends and
entertainment, so can reduce stress. In addition, having a pet can also make people
sympathetic and have more affection for animals.

The paragraph begins with a topic sentence stating what the paragraph will tell us about. The writer may have made a grammatical and syntactical error on the pluralism. Fortunately, the main idea is still understandable. It talks about the role of pets for owners. The following sentences can be seen having a further description about the role to the end of the paragraph. It means that the paragraph does not have a concluding sentence. Having only two from three elements of a paragraph is not a serious problem for this matter, yet the answer seems incomplete. This kind of matter could be understandable if the purpose of the work is to avoid repetition since the explanation could be made simpler. 
Picture 9:

Types of Acnes

\section{Types of Acne}

Almost people usually have different types of acne which appearing in their face. First of all there are papules, this type of acne appears under the surface of the skin, when you feels like a dense, painful bulge, the skin around the bulge looks reddish swollen. However, pimple papules do not have a pus point at the top. Furthermore, Pustules, this type of acne is a lump that is bigger and softer. The base is reddish in color, while the top is white or yellowish in color and appears more raised because it is filled with pus. The last type is cystic acne, this type of acne is in the form of large red bumps, soft-textured due to pus, and will feel painful when you touch it. This type of acne is the most likely to cause scars that are hard to get rid of. Therefore, each type sof acne need its own treatment and care. Then it will be better if you consult first to the dermatologist about your problem.

Source: https://bit.ly/3lgcunY

Talking about acne, the paragraph above is considered to be categorized into good criteria, expected structure and expected content. Differ from the previous data, giving a conclusion means that the student makes an effort to fulfil the instruction. It also makes the paragraph seem complete.

The student as writer begins the paragraph by stating the topic, that is the types of acne. The next sentences which are regarded as part of the supporting sentences, constantly talks about the topic compiled with the description of its appearance. The last two sentences are seen as conclusions related to the type of acne.

Furthermore, the flow of information is organized suited to each element of the paragraph. It is indicated that the students not only understand about the instruction but also understand about the information she wants to deliver. She also has a good ability in delivering the information so that the flow could be smoothen and in order. Similar result is also shown by another student who talks about a kind of sport.

Picture 10:

Football

FOOTBALL

football, popular in Indonesia for 2 reasons. First of all, football has a simple main rule, which is to score a goal against the opponent's goal using limbs other than hands. Therefore, it is easy for people to understand and practice it. Another reason is because football can be played anywhere and with the minimum equipment. Many people play this sport on quiet streets and even in the home yard using simple equipment, such as flip-flops as the goalpost and plastic bottles for the ball. football can be played together with friends. In conclusion, football is popular in Indonesia because this sport has simple rules and is easy to practice by all Indonesians.

Source: https://bit.ly/3Dkti3m 
The paragraph looks simpler and shorter than the previous but it also belongs to having a good criterion. The information is stated clearly and delivered in order. As the previous writer, he is also supposed to have a good ability in communication and understanding the information he conveys. It helps him to write the paragraph as instructed. The opposite belongs to no writing.

The assessment of the paragraph is clear. It also has standards that differ them from another category. No writing does not always mean that the students do not write any paragraph. There are paragraphs and the miss that are not similar to unexpected structure and content.

Unexpected structure seems that the paragraph actually talks about one topic but it writes the explanation into several paragraphs. Unexpected content shows that what they are talking about is not related. On the other hand, no writing shows the condition where the answer given by the students is so far away from the context and the order. The example of no writing is seen in picture 11 .

The picture shows how the student answers the questions. He gave three points and entitled each point with topic sentence, supporting sentence and concluding sentence. Then, he gave each of them one paragraph. It means that there are three paragraphs with three different topics on their work. Indeed, the instruction is to write only a paragraph with one topic.

Besides the amount of paragraph, another way of answering the question is also far from the expectation. He knows about the position of each element and he shows it. Nevertheless, that is not the way of doing the task and not suited to the order. The students do not ask to analyse paragraphs but write their own paragraph while considering the extrinsic and intrinsic element of the paragraph. There is also indication that the paragraph is not written by himself but it was taken from another source. Although he put effort in analysing the position of the topic, supporting and concluding sentences, the paragraph is not him. Therefore, it belongs to no writing. 
Picture 11:

Avocado, PSS Sleman and Anthony Ginting

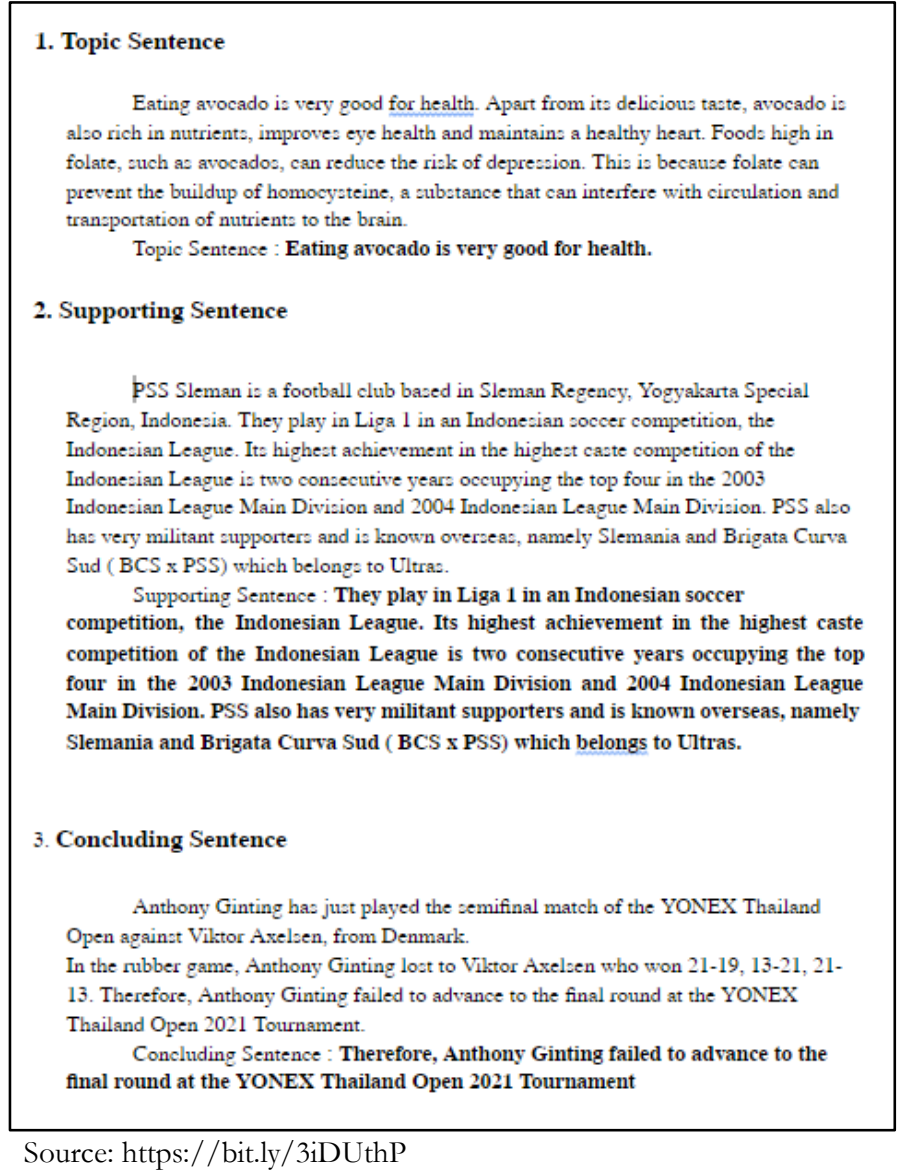

Another student also seems to have a misunderstanding about the order but makes a different mistake than the previous. He gave two paragraphs to his work then analysed the intrinsic element of the paragraph. It is seen from his work as presented in picture 12. He answers the question by mentioning two elements in point. First point is entitled kohesi. He wrote the word in Indonesian spelling. He does the same at the second point. $\mathrm{He}$ wrote koheren, which is an Indonesian spelling. Even he does not give any analysis to his work.

Besides unity, coherence is true written and mentioned in the instruction but it is not the main focus of the order. It is one of the elements that should be considered by students while writing a paragraph.

The issue of plagiarism, as it is found in the previous case, is also indicated to happen in this case. He is intended not to write the paragraph and takes from another source. Therefore, his work belongs to the "no writing" category. 
Picture 12:

Kohesi dan koherensi

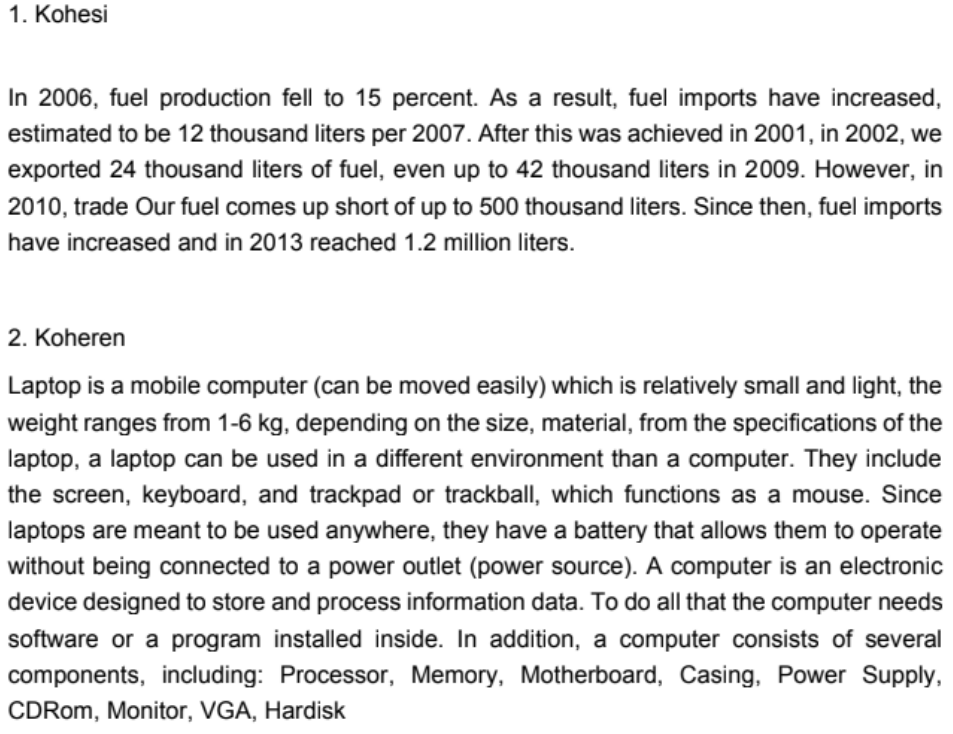

Source: https://bit.ly/3agoL5K

Curiosity is finally paid off to the topic that is chosen by the students. Variety of topics shows their colourful mind. It is about their interest and memory of something. The higher frequency they deal with something, the stronger they remember about it. Hence, the relation between the preferential topic written in paragraph and the mental process are proven. Memory helps them to recall everything that is stuck in their mind.

Furthermore, it is adventurous to understand their ability in writing a paragraph. Firstly, many students' works belong to expected structure and content. It seems that they have no problem with their skill of writing. They have a good ability to understand the instructions and organize ideas. Their way of thinking is good when they write a paragraph. It is shown by the language they arranged in every sentence. The mental process not only helps them to memorize anything related to the topic but also helps them to control their mind so they can focus on one idea and be consistent in discussing it in a whole paragraph.

Secondly, students whose work belongs to expected structure and unexpected content seems to be the dominant. They are able to understand the instruction yet unable to deliver the information. The delivery problem varies on its part. Some of them are correct in only one part, whether the topic sentence, concluding sentence, or supporting sentence. The topic sentence could be said to be correct but the supporting and concluding sentences are incorrect. The others are incorrect in every part due to the loss of unity and coherence even if they are familiar with the topic. Its loss can be related to the mental process of the student. This is because the mental 
process relates to students' minds. Mental process possibly causes incoherence from one sentence to another sentence in one paragraph (Sidabutar, 2016).

Thirdly, the students whose works belong to unexpected structures are predicted to have problem with their understanding of the instruction. Lastly, the students that their works belong to 'no writing' does not mean that she or he does nothing. It seems similar to an unexpected structure but in a different scope. Students with 'unexpected structure and expected content' are predicted not to have understanding that the instruction asked them to unify the paragraph, not separate each element. While students with no writing totally have no understanding of asking for a writing paragraph. They may assume that they only need to analyse the element of paragraphs.

Knowing the result of analysis and its discussion is very beneficial. It answers the problem as stated in the beginning, that is revealing their preferences. Furthermore, it is also helpful and soluble. It is applied to organize the lesson plan and material in order to achieve the goal of fun writing learning. Topics that are found during the analysis and presented in table 1 will be taken into the material. The closer the topic to their interest is expected to get them ease in understanding the lesson and theory. Their skill in writing and the problem of flow information will also be taken as the focus of learning and discussion. The activity of learning should be related to their mental process, especially their way of thinking. Their minds should be trained to link the cause and effect; analyse the general thing to specific and vice versa; and make the concept of information flow (Sidabutar, 2016). Therefore, their skill in writing could be improved in its limited-meeting-andtime English class.

The explanation above clearly gives the unique findings that makes the difference from the previous research. Using the same method but different approach delivers the assessment of meaning through ESL old learner's ability in producing the description of certain pictures (Flores, 2021).

\section{CONCLUSION}

Dealing with the aim of analysis to answer the research problem, some findings could be elaborated. The discussion generally talks about the ESL learners' writing. The analysis firstly focuses on revealing the topics of writing to see their preferences. They prefer to choose any topics that are related to their life and environment, factual, real and interesting. The analysis also reveals that students are able to understand the instruction as well as writing the paragraphs. Nevertheless, the challenge dominantly lies on their ability to organize the information they deliver. It is still the biggest problem seen in their work. These findings of analysis prove that applying psycholinguistics approach in conducting the research is precise to understand their ideas, mind, thought and language. Knowing their preferences and problems in 
writing paragraphs will be beneficial in the aim of arranging the learning lesson and material. In addition, carrying out the suitable approach could make them enjoy joining the learning and makes it easier to understand the lesson dealing with the manner of writing. In the future, it is expected to help us better in reaching learning outcomes. The expectation can be proven by further research. The analysis can be focused on the effect of giving material that is close to students' interest. If this method is proven to help students improve their writing skill, it subsequently leads the teacher to have different views in preparing a lesson plan and to give an updated approach of English learning, considering the needs of improving ESL students' skill in writing an English paragraph.

\section{ACKNOWLEDGEMENT}

This research is conducted by dint of supported parties. The first and the most blessed is presented to Allah for His mercy. The honourable thanks is delivered to LPPM Universitas Amikom Purwokerto for the funding and partnership. Author thanks also delivered to the reviewer and proof-reader's help for publishing this manuscript.

\section{REFERENCES}

Alshammari, S. (2020). "Writing to Learn or Learning to Write". A Critical Review of "English as a Foreign Language" (EFL) Teaching Practices in Writing in Saudi Universities. Research in Education and Learning Innovation Archives, 24, 1-22. https://doi.org/10.7203/realia.24.15867

Ampa, A. T., \& Quraisy, H. (2018). Needs Analysis of the English Writing Skill as the Base to Design the Learning Materials. SHS Web of Conference, 00050, 1-6.

Anh, D. T. N. (2019). EFL Student's Writing Skills: Challenges and Remedies. IOSR Journal of Research \& Method in Education, 9(6), 74-84. https://doi.org/10.9790/7388-0906017484

Ariyanti, A. (2016). The Teaching of EFL Writing in Indonesia. Dinamika Ilmu, 16(2), 263-277. https://doi.org/10.21093/di.v16i2.274

Dasril, Zaim, M., \& Ningsih, K. (2019). Coherence and Unity of Students' Writing on Background of the Study of Research Proposal. 1st International Conference on Education, Social Science and Humanities, 335, 399 404. https://doi.org/10.2991/icesshum-19.2019.65

Dewi, A. S. S. P. (2016). Kemampuan Menulis Paragraf Eksposisi Siswa Kelas X SMA Negeri 12 Konawe Selatan. Jurnal Humanika, 1(16), 1-19. 
http://ojs.uho.ac.id/index.php/HUMANIKA/article/view/741

Fatmah, D., Suhartono, S., \& Gumono, G. (2020). Peningkatan Kemampuan Menulis Paragraf Deduktif dan Induktif dengan Menggunakan Model Picture and Picture di Kelas X Program IPS SMA Negeri 1 Kepahiang. Silampari Bisa: Jumal Penelitian Pendidikan Bahasa Indonesia, Daerah, Dan Asing, 3(1), 27-43. https://doi.org/10.31540/silamparibisa.v3i1.935

Flores, J. A. A. (2021). The semiotics of writing: How adult L2 learners with emergent literacy make meaning in assessment texts through writing. Journal of Second Language Writing, 51(February 2020), 100793. https://doi.org/10.1016/j.jslw.2021.100793

Hidayati, K. H. (2018). Teaching Writing to EFL Learners: An Investigation of Challenges Confronted by Indonesian Teachers. Langkawi: Journal of The Association for Arabic and English, 4(1), 21-31. https://doi.org/10.31332/lkw.v4i1.772

Huda, M. (2018). Blended Learning: Improvisasi dalam Pembelajaran Menulis Pengalaman. Lensa: Kajian Kebahasaan, Kesusastraan Dan Budaya, $8(2), 117-130$.

Indriyastuti, A. (2019). Peningkatan Keterampilan Menulis Letter of Opinion ( Surat Opini) pada Mata Pelajaran Bahasa Inggris dengan Menggunakan Media Fantastic Card di Kelas XI. Lensa: Kajian Kebahasaan, Kesusastraan Dan Budaya, 9(1), 26-45.

Isgiarno, Y. C., Cahyono, B. Y., \& Rahmaningtyas, H. (2020). Increasing EFL Students' Writing Skill Using Jigsaw and Online Searching Strategy. IJEE (Indonesian Journal of English Education), 7(1), 97-110. https://doi.org/10.15408/ijee.v7i1.16383

Ivana, L., Sugiarti, S., Mujianto, G., Prihatini, A., \& Pangesti, F. (2019). Kemampuan Siswa dalam Menyusun Gagasan Utama dan Gagasan Penjelas pada Teks Laporan Hasil Observasi dengan Media Kartu Observasi. Lensa: Kajian Kebahasaan, Kesusastraan Dan Budaya, 9(1), 6176.

Kadir, H. (2017). Peran Pendekatan Psikolinguistik dalam Membangun Pola Inetraksi Pembelajaran di Kelas. Wahana Didaktika, 15(2), 1-11.

Koura, A. A., \& Zahran, F. A. (2017). Using Habits of Mind to Develop EFL Writing Skills and Autonomy. Arab World English Journal, 8(4), 183-198. https://doi.org/10.24093/awej/vol8no4.12

Kurniawan, K., Pratama, R. K., \& Yogyakarta, U. N. (2017). Implikasi Psikolinguistik dalam Pembelajaran Babasa. November. https://doi.org/10.13140/RG.2.2.22037.83687 
Lisnawati, I. (2008). Psikolinguistik dalam Pembelajaran Bahasa. Educare: Jurnal Pendodikan Dan Budaya.

Mohammad, T., \& Hazarika, Z. (2016). Difficulties of Learning EFL in KSA: Writing Skills in Context. International Journal of English Linguistics, 6(3), 105-117. https://doi.org/10.5539/ijel.v6n3p105

Monalisa, M. (2017). Interaction in EFL Writing Class: Lecturers' Reflection. IJEE (Indonesian Journal of English Education), 4(2), 144-155. https://doi.org/10.15408/ijee.v4i2.8323

Muslim, I. M. (2014). Helping EFL Students Improve their Writing. International Journal of Humanities and Social Science, 4(2), 105-112.

Natsir, N. (2017). Hubungan psikolinguistik dalam pemerolehan dan pembelajaran bahasa. Jurnal Retorika, 10(1), 20-29.

Okasha, M. A., \& Hamdi, S. A. (2014). Using Strategic Writing Techniques for Promoting EFL Writing Skills and Attitudes. Journal of Language Teaching and Research, 5(3), 674-681. https://doi.org/10.4304/jltr.5.3.674-681

Sabarua, J. O. (2017). Psikolinguistik dalam pendidikan.

Saptenno, W. Y., \& Souisa, T. R. (2021). Student's Peer Feedback in EFL Writing Class of English Study Program. Huele: Journal of Applied Linguistics, Literature and Culture, 1(1), 1-16.

Setiyorini, T. J., Dewi, P., \& Masykuri, E. S. (2020). The Grammatical Error Analysis Found in Students' Composition. Lensa: Kajian Kebahasaan, Kesusastraan Dan Budaya, 10(2), 218-233.

Sidabutar, R. B. (2016). Kemampuan Berbahasa Anak dalam Buku Harian Ditinjau dari Kajian Memori, Pikiran, dan Bahasa. Cendekia, 10(1), 29_ 40.

Tuan, L. T. (2010). Enhancing EFL Learners 'Writing Skill via Journal Writing. Canadian Center of Science and Education, 3(3), 81-88.

Yunhadi, W. (2013). Analysis on paragraph writing of the second semester students of english department of university of kutai kartanegara. 